\title{
ДЕЕТИМОЛОГІЗАЦІЯ В УКРАЇНСЬКІЙ МОВІ
}

Колоїз Ж. В. Деетимологізація в українській мові.

У статті йдеться про деетимологізацію як один із семантичних процесів, який модифікує основу лексичного значення i, відповідно, позначається на морфемний структурі слова. Через зіставлення історично споріднених одиниць реконструюються найдавніші форми, виявляються ті зміни, які відбулися у відповідних словах у процесі їхнього функціонування в мові, а також з'ясовуються первинні словотвірні зв'язки.

Ключові слова: деетимологізація, мотивація, похідна / непохідна основа. 
Колоиз Ж. В. Деэтимологизация в украинском языке.

В статье рассматривается деэтимологизация как один из семантических процессов, который модифицирует основу лексического значения и, соответственно, отображается на морфемной структуре слова. Путем сопоставления исторически родственных единиц реконструируются древние формы, анализируются те изменения, которые запечатлены в соответствующих словах в процессе их функционирования в языке, а также определяются первичные словотворческие связи.

Ключевые слова: деэтимологизация, мотивация, производная / непроизводная основа.

Koloyiz Zh. V. Detimologization in Ukrainian language.

The article deals with the deetimologization as a semantic process, which modifies the base of lexical meaning and thus influences the word morpheme structure. The ancient forms are reconstructed by comparison of historically related units, those changes are analyzed which are embodied in the appropriate words during their functioning in language, and also primary wordformation connections are defined.

Key words: deetimologization, motivation, derivative / non derivative basis.

Появою терміна деетимологізація завдячують українському мовознавцеві Л.А. Булаховському, який вперше дослідив це явище на російськомовному матеріалі, звернувши увагу на те, що етимологічно близьке значення споріднених слів, яке первинно досить чітко відображалося у свідомості мовців при використанні відповідного слова, з часом може втрачати здатність вступати 3 цими словами в семантичний зв'язок. „Якесь слово, тобто певний звуковий комплекс і соціально зумовлене його значення як продукт психологічної обробки ряду значеннєвих елементів, що становлять єдине ціле, деетимологізується - перестає нагадувати інше слово або слова, з якими так чи так раніше було пов'язане, утрачає здатність осмислюватися разом $з$ ними у складі одного „гнізда”, стає в лексичній системі мови етимологічно більш ізольованим", - розмірковує вчений [1, 345]. Згодом науковці неодноразово розробляли окреслену проблему, їхні багаторічні пошуки сприяли появі й більш чіткого визначення: деетимологізація - це „втрата словом етимологічної мотивованості внаслідок затемнення його семантичного та словотвірного відношення до мотивувального слова (кореня) і здебільшого його морфемної структури" [6, 123]. Причини втрати колишніх значеннєвих зв'язків зазвичай залишаються незрозумілими та необгрунтованими, обмежуються переважно констатацією фактів, що стали об'єктом вивчення такої мовознавчої царини, як етимологія. Хоч, безумовно, наявні певні спроби систематизації і причин деетимологізації (наприклад, а) семантичне розходження спільнокореневих слів; б) утрата складових морфем слова - мотивувального кореня та афіксів; в) фонетичні i, як наслідок, морфемні зміни, що порушують зв'язок однокореневих слів і т. ін. $[6,123])$.

Мета нашої статті полягає в тому, аби дослідити деетимологізацію як один із семантичних процесів, який модифікує основу лексичного значення i, відповідно, позначається на морфемній структурі слова. Розвідка спрямована на поглиблення теми „Історичні зміни в морфемній структурі 
слова" і засвідчує взаємодію морфеміки з лексикологією, зокрема з однією з основних категорій останньої - лексичним значенням.

Лексичне значення слова визначається по-різному, зокрема і як „певне відображення предмета, явища або відношення у свідомості, що входить до структури слова в ролі так званої внутрішньої його сторони, стосовно до якої звучання слова виступає як матеріальна оболонка, необхідна не лише для вираження значення і для повідомлення його іншим людям, а й для самого його виникнення, формування, існування і розвитку" [5, 97-98]. Іншими словами, воно формується через внутрішню форму, що, згідно 3 теорією О.О. Потебні, дає назву слову, визначає його звукове оформлення і тим самим через це оформлення виражає його значення як сукупність об'єктивних ознак: „На слово не можна дивитися як на вираження готової думки ... слово є вираженням думки настільки, наскільки служить засобом для їі оформлення; внутрішня форма, єдиний об'єктивний зміст слова, має значення тільки тому, що видозмінює й удосконалює ті агрегати сприйняття, на які наштовхується в душі' $[4,29]$. Внутрішня форма слова розглядається вченим як засіб аперцепції, як посередник між новопізнаним і набутим лінгвальним досвідом; вона експлікує образ, покладений в основу передусім узуально закріпленої одиниці.

На думку В.О. Горпинича, внутрішня форма слова - „це той зміст, від якого походить лексичне значення слова, це та ознака, яка береться за основу номінації, це засіб мотивації лексичного значення слова" [2, 64]. Уважають, що первинно всі повнозначні одиниці мали виразну внутрішню форму, однак, пройшовши складний історичний шлях розвитку, частина 3 них перейшла до розряду етимологічно непрозорих, як-от: гіркий, ловкий, добрий, старий, хитрий. Прикметники гіркий (походить від праслов'янського *gorĕti, що вживалося в значенні „палати, пекти”) і ловкий (походить від праслов’янського *lovītī - „виявляти спритність”) репрезентують давній суфікс -к зі значенням „схильний до того, що названо твірним словом" (пор.: варити $\rightarrow$ варкий, палати $\rightarrow$ палкий, хитати $\rightarrow$ хиткий, лунати $\rightarrow$ лункий і т. ін.). Прикметники добрий, старий, хитрий засвідчують давній суфікс -p зі значенням „більша міра ознаки, названої твірним словом”: добрий (*dobrъ - „відповідний, корисний”) утворилося від іменникової основи *doba - „щось стосовне, властиве”; старий та хитрий є віддієслівними утвореннями, спродукованими на базі дієслів*stāti, *chūtati (пор.: у староукраїнській мові лексема старий використовувалася в значенні „сталий, міцний”, хитрий - у значенні „спритний, меткий”). 3 позицій етимологічного аналізу всі ці пари слів (вихідне і похідне) є спільнокореневими. Деякі з них ілюструють словотвірні ланцюжки (горіти $\rightarrow$ гіркий $\rightarrow$ гірчиця) чи словотвірні парадигми (доба $\rightarrow$ добрий і подоба; стати $\rightarrow$ старий і сталий), що істотно відрізняються від сучасних, оскільки зв'язки історично спільнокореневих слів повністю втрачені. Можна вважати, що процес деетимологізації названих лексем повністю завершив- 
ся, вони втратили свою етимологічну мотивованість у результаті затемнення семантичного та словотвірного відношення до мотивувальних слів. Було б неправильно стверджувати, що результати деетимологізації $є$ досить широко представленими в сучасній українській мові. Однак це явище так чи інакше виявляється в різних лексико-граматичних розрядах і потребує належної уваги. У нашій статті більш детально зупинимося на аналізі слів, які з синхронічного погляду є неподільними, здебільшого становлять вершини словотвірних гнізд, однак не є такими в діахронічному аспекті. У парадигмі історично споріднених (спільнокореневих) одиниць вони займають не вихідну (первинну), а похідну (вторинну) позицію.

Безпека -,стан, коли кому-небудь, чому-небудь ніщо не загрожує”. 3 позицій сучасного словотвору кваліфікується як таке, що має неподільну основу, оскільки поєднує у своєму складі кореневу (безпек-) та флексійну матеріально виражену (-a) морфеми. Згідно з етимологією лексема має семантичне та словотвірне відношення до дієслова пекти (*pekti), яке є його давньою мотивувальною базою (інше пояснення: утворене внаслідок поєднання прийменника *bez та іменника *peka - „турбота, клопоти”), тобто дозволяє вичленувати кореневу морфему, відмінну від сучасної (-nек-), що представлена (з різними фонетичними модифікаціями) також у словах опіка, піклуватися, печаль. Деетимологізація, яка знівелювала семантичну основу вихідного лексичного значення, спричинила й відповідну перебудову в морфемній структурі слова (слів).

Дача - ,літній будинок для відпочинку за містом”. 3 позицій сучасного словотвору кваліфікується як таке, що має неподільну основу, оскільки поєднує у своєму складі кореневу (дач-) та флексійну матеріально виражену (-a) морфеми. Згідно з етимологією лексема має семантичне та словотвірне відношення до дієслова дати (*dati), яке є його давньою мотивувальною базою. У процесі словотворення до твірної основи було додано суфікс *j (*dat+j+a), що спричинив відповідні фонетичні модифікації (пор.: *svétiti

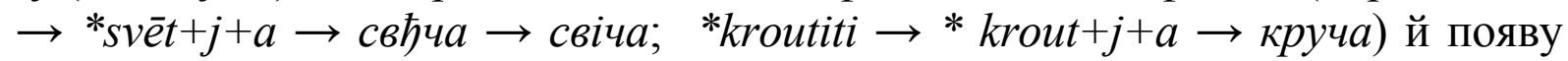
звукового комплексу - дача, за яким спочатку закріпилося значення ,земля, подарована володарем”. Згодом через звуження (,будинок на подарованій землі”) новоутворена матеріальна форма вираження починає використовуватися для означення більш конкретної реалії об'єктивної дійсності й отримує якісно нову семантику, відому сучасному носієві української мови.

Держсава - ,апарат політичної влади в суспільстві”. 3 позицій сучасного словотвору кваліфікується як таке, що має неподільну основу, оскільки поєднує у своєму складі кореневу (держсав-) та флексійну матеріально виражену (-a) морфеми. Згідно з етимологією лексема має семантичне та словотвірне відношення до дієслова держати (* deržati - „тримати, володіти” (пор.: застаріле значення звукового комплексу держава - „маєток, помістя, володіння"), яке є його давньою мотивувальною базою, що дозво- 
ляє вичленувати кореневу морфему, відмінну від сучасної (держк-), представлену також у словах держсак, держсално.

Кориця - ,висушена кора коричного дерева, що іï вживають як прянощі для кондитерських виробів, а також у медицині та парфумерії ”. 3 позицій сучасного словотвору кваліфікується як таке, що має неподільну основу, оскільки поєднує у своєму складі кореневу (кориц-) та флексійну матеріально виражену (-a) морфеми. Згідно з етимологією лексема має семантичне та словотвірне відношення до іменника кора (*kora), яке є його давньою мотивувальною базою, що дозволяє вичленувати кореневу морфему, відмінну від сучасної (кор-), яка представлена (з різними фонетичними модифікаціями) також у словах коричневий, корба (,дерев'яна посудина для води”), короб (,,тара з лубу, бересту, лози”), корецьь (,кухоль чи ківш із держаком”), корито (,„дерев’яна довгаста посудина”).

Косинка - ,трикутна жіноча хустка, яку носять на голові або шиї”. 3 позицій сучасного словотвору кваліфікується як таке, що має неподільну основу, оскільки поєднує у своєму складі кореневу (косинк-) та флексійну матеріально виражену (-a) морфеми. Згідно з етимологією лексема має семантичне та словотвірне відношення до прикметника косий (*kosǔs - „обрубаний, обрізаний”), яке є його давньою мотивувальною базою, що дозволяє вичленувати кореневу морфему, відмінну від сучасної (кос-), яка представлена (з різними фонетичними модифікаціями) також у словах коca, кісниця („сіножать”), косяк, косина', косинець, косинчик. До етимологічно спорідненого ряду можна віднести й дієслово чесати (*kesati $\rightarrow$ *česati - „різати, скребти”), що засвідчує історичне чергування - зміну задньоязикового [*k] перед голосним переднього ряду [*e] на [*c] $([u])$.

Kостур - „висока палиця, на яку спираються і якою користуються як опорою під час ходіння хворі на ноги чи безногі люди; милиця". 3 позицій сучасного словотвору кваліфікується як таке, що має неподільну основу, оскільки поєднує у своєму складі кореневу (костур-) та флексійну нульову (ஜ́) морфеми. Згідно з етимологією лексема має семантичне та словотвірне

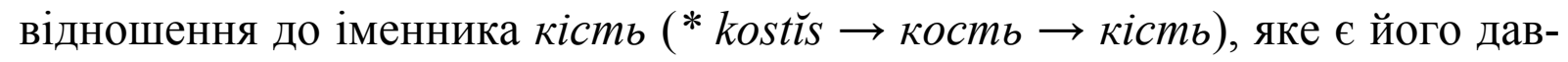
ньою мотивувальною базою і дозволяє вичленувати кореневу морфему, відмінну від сучасної (кост-). Аналогічна морфема (інваріантна чи аломорфна) засвідчена і в етимологічно спільнокореневих словах кістка, костиль, кострец̧ь („нижня частина крижів”), пакість. Остання лексема

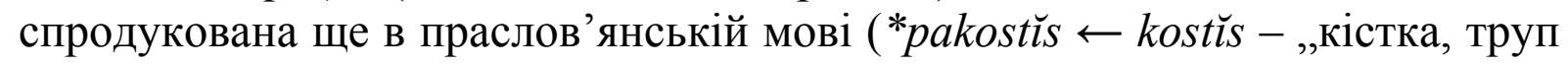
забитого; останки трупа”).

Мавка (навка) - „казкова лісова істота”. 3 позицій сучасного словотвору кваліфікується як таке, що має неподільну основу, оскільки поєднує у своєму складі кореневу (мавк-) та флексійну матеріально виражену (-a) морфеми. Згідно з етимологією лексема має семантичне та словотвірне відношення до іменника нав ( nav̌s - „мрець, смерть”), яке є його давньою мотивувальною базою і дозволяє вичленувати кореневу морфему, відмінну 
від сучасної (мав-(нав-). Аналогічна морфема засвідчена і в етимологічно спільнокореневих словах мавкати (нявкати), мавський (навський) (Великдень) - „день поминання померлих”.

Налисник - „тонкий млинець, що в нього загортається якась начинка". 3 позицій сучасного словотвору кваліфікується як таке, що має неподільну основу, оскільки поєднує у своєму складі кореневу (налисник-) та флексійну нульову (ஜ́) морфеми. Згідно з етимологією лексема має семантичне та словотвірне відношення до іменника лист (*listǔs), яке $є$ його давньою мотивувальною базою (млинець випікали на капустяному листі), що дозволяє вичленувати аломорфний корінь, відмінний від сучасного (лис-), представлений у словах листя, листок, листовий.

Намітка - „покривало на голову в жінок поверх очіпка". 3 позицій сучасного словотвору кваліфікується як таке, що має неподільну основу, оскільки поєднує у своєму складі кореневу (намітк-) та флексійну матеріально виражену (-a) морфеми. Згідно з етимологією лексема має семантичне та словотвірне відношення до дієслова наметати (*nametati), яке є його давньою мотивувальною базою, що дозволяє вичленувати кореневу морфему, відмінну від сучасної (мim-), яка представлена (з різними фонетичними модифікаціями) також у словах замет, заміт, намет, омета (,пола; край одягу”), ометь (,легкий сніг на деревах”), ометиия (,вид вишивки”).

Hanacmb - „біда, нещастя, неприємність”. 3 позицій сучасного словотвору кваліфікується як таке, що має неподільну основу, оскільки поєднує у своєму складі кореневу (anacm'-) та флексійну нульову (ஜ́) морфеми. Згідно з етимологією лексема має семантичне та словотвірне відношення до дієслова наnacmu (*napasti $\leftarrow{ }^{*}$ pasti), яке $\epsilon$ його давньою мотивувальною базою, що дозволяє вичленувати кореневу морфему, відмінну від сучасної (nac-).

Оливо - „глазур для глиняного посуду, яка ще не застигла; свинець”. 3 позицій сучасного словотвору кваліфікується як таке, що має неподільну основу, оскільки поєднує у своєму складі кореневу (олив-) та флексійну матеріально виражену (-о) морфеми. Згідно з етимологією лексема має семантичне та словотвірне відношення до дієслова лити (*liti), яке $є$ його давньою мотивувальною базою, що дозволяє вичленувати кореневу морфему, відмінну від сучасної (лив-), яка представлена (з різними фонетичними модифікаціями) також у словах поливка, полив'яний, олівець, олив'янка („бабка, налита оливом”), олівник (,ливарник”).

Onона - „повстяне покривало для захисту коней від холоду; попона”. 3 позицій сучасного словотвору кваліфікується як таке, що має неподільну основу, оскільки поєднує у своєму складі кореневу (опон-) та флексійну матеріально виражену (-a) морфеми. Згідно з етимологією лексема має семантичне та словотвірне відношення до дієслова пнути (*pǔnonti $\rightarrow$ nънy$m u)$, яке $\epsilon$ його давньою мотивувальною базою, що дозволяє вичленувати кореневу морфему, відмінну від сучасної (пон-), яка представлена (з різ- 
ними фонетичними модифікаціями) також у словах путо, спина, опинка (,плахта, запаска").

Паломник - ,той, хто відвідує святі місця; прочанин”. 3 позицій сучасного словотвору кваліфікується як таке, що має неподільну основу, оскільки поєднує у своєму складі кореневу (паломник-) та флексійну нульову (ஜ́) морфеми. Згідно з етимологією лексема має семантичне та словотвірне відношення до іменника пальма (*palüma $\rightarrow$ nалъма), яке є його давньою мотивувальною базою (буквально означало ,той, що несе пальмову гілку”), що дозволяє вичленувати кореневу морфему, відмінну від сучасної (палом-).

Паляниця - „хлібина 3 пшеничного борошна, певним чином замішаного”. 3 позицій сучасного словотвору кваліфікується як таке, що має неподільну основу, оскільки поєднує у своєму складі кореневу (паляниц-) та флексійну матеріально виражену (-a) морфеми. Згідно з етимологією лексема має семантичне та словотвірне відношення до дієслова палити (* paliti), яке $\epsilon$ його давньою мотивувальною базою, що дозволяє вичленувати кореневу морфему, відмінну від сучасної (пал-), яка представлена (з різними фонетичними модифікаціями) також у словах палятина („щось палене”), паляр (,винокур”), паляндрувати (,знищувати вогнем, палити”).

Пам'ять - ,здатність зберігати та відтворювати у свідомості минулі враження". 3 позицій сучасного словотвору кваліфікується як таке, що має неподільну основу, оскільки поєднує у своєму складі кореневу (nam'яm'-) та флексійну нульову (ஜ́) морфеми. Згідно з етимологією лексема має семантичне та словотвірне відношення до дієслова м'яти (*menti), яке є його давньою мотивувальною базою, що дозволяє вичленувати кореневу морфему, відмінну від сучасної (м'я-), яка представлена (з різними фонетичними модифікаціями) також у словах мнецьь (,кожум'яка”), м'яло („макогін”), розминка, поминати, поминки.

Пасіка - „місце, де стоять вулики; ділянка лісу призначена для зрубу”. 3 позицій сучасного словотвору кваліфікується як таке, що має неподільну основу, оскільки поєднує у своєму складі кореневу (пасік-) та флексійну матеріально виражену (-a) морфеми. Згідно з етимологією лексема має семантичне та словотвірне відношення до дієслова посікти ( *pōsēkti $\rightarrow$ nachка $\rightarrow$ nасіка), яке є його давньою мотивувальною базою, що дозволяє вичленувати кореневу морфему, відмінну від сучасної (сік-), яка представлена (з різними фонетичними модифікаціями) також у словах просіка, пасічник, січ, січка (,посічена солома”), січкавниця („шатківниця”), відсіч, січень.

Пиріг - „печений виріб із тіста 3 начинкою”. 3 позицій сучасного словотвору кваліфікується як таке, що має неподільну основу, оскільки поєднує у своєму складі кореневу (пupiz-) та флексійну нульову (ஜ́) морфеми. Згідно $з$ етимологією лексема має семантичне та словотвірне відношення до іменника пup (*pirǔs Ł *piti), яке є його давньою мотивувальною базою, що дозволяє вичленувати кореневу морфему, відмінну від сучасної (nu-), яка 
представлена (з різними фонетичними модифікаціями) також у словах пuво, пивниця, питво, питун, п'явка, пияцттво, пійло, напій, пиячити.

Півень - „свійський птах із червоним гребенем на голові, пишним хвостом і шпорами на ногах". 3 позицій сучасного словотвору кваліфікується як таке, що має неподільну основу, оскільки поєднує у своєму складі кореневу (півен'-) та флексійну нульову (ஜ́) морфеми. Згідно з етимологією лексема має семантичне та словотвірне відношення до дієслова співати (*péti), яке $\epsilon$ його давньою мотивувальною базою, що дозволяє вичленувати кореневу морфему, відмінну від сучасної (ni-), яка представлена (з різними фонетичними модифікаціями) також у словах cnis, cniвeu̧b, заспів, пісня, пісняр.

Плащцаниця - ,полотнище із зображенням Христа у труні”. 3 позицій сучасного словотвору кваліфікується як таке, що має неподільну основу, оскільки поєднує у своєму складі кореневу (плащаниц-) та флексійну матеріально виражену (-a) морфеми. Згідно з етимологією лексема має семантичне та словотвірне відношення до іменника плащ̧ (*plašč̌̌s $\leftarrow$ *plastǔs), яке $\epsilon$ його давньою мотивувальною базою, що дозволяє вичленувати кореневу морфему, відмінну від сучасної (плащ-), яка представлена (з різними фонетичними модифікаціями) також у словах пластинка, пластівецьь, пластун, плоский, площца, площинна.

Повінь - ,,розлиття річки, значне підвищення рівня води у водоймі”. 3 позицій сучасного словотвору кваліфікується як таке, що має неподільну основу, оскільки поєднує у своєму складі кореневу (повін'-) та флексійну нульову (ஜ́) морфеми. Згідно з етимологією лексема має семантичне та словотвірне відношення до іменника вода ( $\epsilon$ результатом спрощення праслов'янської форми *povodǐňs (поводьнъ), яке є його давньою мотивувальною базою, що дозволяє вичленувати аломорфний корінь, відмінний від сучасного (ві-).

Притча - „коротке повчальне оповідання”. 3 позицій сучасного словотвору кваліфікується як таке, що має неподільну основу, оскільки поєднує у своєму складі кореневу (притч-) та флексійну матеріально виражену (-a) морфеми. Згідно з етимологією лексема має семантичне та словотвірне відношення до дієслова ткнути (*tǔknonti $\rightarrow{ }^{*}$ pritǔknonti $\rightarrow{ }^{*}$ pritǔk $+j+a \rightarrow$ nритъча), яке є його давньою мотивувальною базою, що дозволяє вичленувати кореневу морфему, відмінну від сучасної (mu-), яка модифіковано представлена також у словах тикати, затичка.

Отже, деетимологізація модифікує первинну основу лексичного значення, переводить ту чи ту лексему з розряду мотивованих до немотивованих. До того ж у процесі історичного розвитку мови можуть змінюватися не лише значення окремих слів, їхній фонетичний склад, але і їхня морфемна будова. Через зіставлення історично споріднених одиниць можна реконструювати найдавніші форми, виявити ті зміни, які відбулися у відповідних словах у процесі їхнього функціонування в мові, а також з’ясувати 
первинні словотвірні зв'язки. Зміна статусу аналізованих слів (з похідною $\rightarrow$ непохідною основою) здійснюється в результаті „затемнення” первинного плану змісту, що спричиняє появу нових образно-асоціативних зв'язків довербальної та вербальної дійсності.

\section{Література}

1. Булаховский Л. А. Деэтимологизация в русском языке / Л. А. Булаховский // Вибрані праці в 5-и томах. - К. : Наукова думка, 1975. - Т. 3. - С. 345-372.

2. Горпинич В. О. Українська словотвірна дериватологія / В. О. Горпинич. Дніпропетровськ, 1998. - 189 с.

3. Етимологічний словник української мови: У 7-и томах / [упорядн.: Болдирєв Р. В., Коломієць В. Т., Лукінова Т. Б. та ін.]. - К. : Наукова думка, 1982. T.1. -631 c.; 1985. - T. 2. -570 c.; 1989. - T. 3. - 552 c.; 2003. - T. 4. -656 c.; 2006. - T. 5. -704 c.

4. Потебня А. А. Мысль и язык / А. А. Потебня // Теоретическая поэтика. - М. : Наука, 1990. - С.22-55.

5. Сучасна українська літературна мова: Підручник / [Грищенко А. П., Мацько Л. І., Плющ М. Я. та ін.]; за ред. А. П. Грищенка. - [3-є вид., доповн.]. - К. : Вища школа, 2002. - 439 с.

6. Українська мова: Енциклопедія / [упорядн.: Русанівський В. М., Тараненко О. О., Зяблюк М. П. та ін. ] - К. : Українська енциклопедія, 2000. - С. 123-124. 